Pension Politics in Three Small States: Denmark, Sweden and the Netherlands Author(s): Karen M. Anderson

Reviewed work(s):

Source: The Canadian Journal of Sociology / Cahiers canadiens de sociologie, Vol. 29, No. 2, Special Issue on Social Policy: Canadian and International Perspectives (Spring, 2004), pp. 289312

Published by: Canadian Journal of Sociology

Stable URL: http://www.jstor.org/stable/3654697

Accessed: 21/11/2011 09:35

Your use of the JSTOR archive indicates your acceptance of the Terms \& Conditions of Use, available at http://www.jstor.org/page/info/about/policies/terms.jsp

JSTOR is a not-for-profit service that helps scholars, researchers, and students discover, use, and build upon a wide range of content in a trusted digital archive. We use information technology and tools to increase productivity and facilitate new forms of scholarship. For more information about JSTOR, please contact support@ jstor.org. 


\title{
Pension Politics in Three Small States: Denmark, Sweden and the Netherlands
}

\author{
Karen M. Anderson
}

Abstract: This article emphasizes class politics and path dependence in accounting for the development of pension regimes in Sweden, Denmark and the Netherlands. The political strength of the Swedish Social Democratic Party in alliance with the trade unions resulted in the emergence of a statist pension system. In the Netherlands and Denmark, a politically weak and divided left settled for collectively regulated but privately organized supplementary pensions. However, the Dutch and Danish cases suggest that several types of pension regime structure are capable of producing "social democratic" outcomes such as poverty alleviation, reducing income inequality, and covering various risk profiles. In both countries, private occupational pensions thus produced outcomes similar to those of Sweden. These historical choices decisively shaped the subsequent development of pensions.

Résumé: Cet article met l'accent sur la politique de classes et la continuité institutionnelle (path dependence) pour expliquer le développement des régimes de pension en Suède, au Danemark et aux Pays-Bas. La puissance politique du Parti Social Démocrate suédois dans le cadre de son alliance avec les syndicats a provoqué l'émergence d'un système de pension étatiste. Aux Pays-Bas et au Danemark, une gauche divisée et politiquement faible s'est contentée d'un système de pensions complémentaires régulé collectivement mais organisé de manière privée. Cependant, les cas néerlandais et danois suggèrent que différents types de structures institutionnelles peuvent produire des résultats "sociaux démocrates" tels que la réduction de la pauvreté, la réduction des inégalités, et la couverture de différents profils de risque. Dans ces deux pays, des pensions privées ont donc produit des résultats semblables à ceux du système suédois. Ces choix historiques ont profondément influencé les développements ultérieurs de ces systèmes de pension.

Implicit in much of the welfare state development literature is the assumption that only the public sector can deliver outcomes commonly associated with the "social democratic regime" (Esping-Andersen, 1990). This is especially true for pensions, where publicly organized retirement provision was frequently 
considered the best vehicle for alleviating poverty in old age, reducing income inequality among pensioners, and promoting income equality between pensioners and wage earners. Comparative analysis of pension regimes in Sweden, Denmark and the Netherlands suggests that the public sector is not necessarily the only path leading to equality and solidarity. All three countries provide universal basic pensions, but the three systems diverge in terms of supplementary coverage. The Swedish system includes public, earnings-related benefits for all wage earners, whereas Danish and Dutch occupational pensions are organized in the private sector. Although occupational pensions are privately organized, the Danish and Dutch pension regimes deliver outcomes similar to Sweden's. Old age poverty levels are similar in all three countries, as is income inequality among pensioners.

Comparison of the Swedish, Dutch and Danish pension systems suggests that there are multiple institutional pathways toward similar outcomes (Huber, Ragin, and Stephens, 1993; Van Kersbergen, 1995), and this article draws on this tradition by emphasizing the role of party politics and path dependence. The article emphasizes the political mobilization of the left and its coalitions with other societal groups to explain different paths toward similar outcomes. In Sweden, Social Democratic hegemony and union strength resulted in the emergence of a statist pension system. In the Netherlands and Denmark, the weakness of the political left necessitated cooperation with confessional and liberal groups respectively, and these left their mark primarily in the organization of occupational pensions. In both countries, a politically weak left settled for collectively regulated but privately organized occupational pensions that, despite their location within the market rather than the state sphere, produce outcomes similar to Sweden's. These historical choices decisively shaped the subsequent development of pensions.

\section{The Three Pension Systems}

Until recently, Sweden was usually seen as the prototype of the social democratic pension regime because the public sector dominated pension provision (Esping-Andersen, 1990). The Swedish system also generated large publicly controlled pension funds (AP Funds); in 1992, the AP Funds equalled $35 \%$ of GDP (Proposition 1993/94: 250, 16). Collectively bargained occupational pensions covering $90 \%$ of the labour force topped up public benefits. Denmark and the Netherlands are typically considered weak cases of social democratic pension policy, because Danish and Dutch social democrats failed to introduce generous public supplementary pensions. The Danish pension system is marked by universal basic provision, topped up by modest public supplementary pensions and increasingly important (private) labour market pensions. The Dutch system combines a public flat rate pension with mandated private occupational pensions based on the principle of solidarity. 
Despite these institutional differences, the three pension regimes deliver broadly similar social outcomes. Poverty rates among the retired in all three countries are among the lowest in the world, as are levels of income equality among pensioners and between pensioners and wage earners. Table 1 shows poverty rates among older persons in 11 rich countries according to the two most common methods of determining poverty rates. Sweden shows the lowest poverty rate, closely followed by Denmark and the Netherlands. In Disney and Whitehouse's (2002: 20) study of the economic well-being of older people in 16 rich countries, Denmark had the lowest level of income inequality among pensioners, followed closely by Sweden, Australia, Finland, and the Netherlands. ${ }^{1}$

The three pension regimes also deliver similar results in other ways. All three pension systems have a relatively high degree of funding (see table 2). All three pension systems also cover a variety of risk profiles because all citizens receive basic coverage via the basic pension. Finally, recent changes in all three pension systems significantly strengthen work incentives. The latest round of reforms in all three countries tightened the link between contributions and benefits and reduced incentives for early retirement. The Netherlands in particular has taken significant steps toward reducing early exit (Visser and Hemerijck, 1997). In the 1970s and 1980s, the supplementary pension system (along with disability and unemployment insurance) provided an attractive early exit route for redundant wage earners (Trommel, 1995). Dutch early exit rates remain stubbornly high despite this progress. The OECD (2003) reports that the effective retirement age for men in Sweden was 63.8 in the period 1995-2000, 64.3 for Denmark and 60.7 in the Netherlands. The effective female retirement age in the same period shows a similar pattern: in Sweden it is 62.5, 60.6 in Denmark and 59 in the Netherlands (OECD, 2003: 54).

In short, these three pension systems are relatively resistant to both endogenous and exogenous pressures. Endogenous pressures, including changing family patterns, the growth of non-standard work, etc., do not lead to increased poverty among retirees because the basic pension provides a minimum level of coverage, despite career interruptions. Exogenous pressures such as the financial market integration and EMU are less likely to lead to pressure on public budgets because pensions are partially or fully funded. Thus although the Netherlands and Denmark rely mainly on the private sector for incomerelated benefits, outcomes (as defined above) are broadly similar to Sweden's. The Dutch and the Danes have followed a pension path that is less statist than the Swedish, but only in terms in supplementary pension provision. All OECD countries regulate private pensions in some way; the question is whether and

1. For similar results, see Hauser (1998). 
292 Canadian Journal of Sociology

Table 1. Poverty Rates for the Elderly in the 1990s

\begin{tabular}{lccc} 
Country & Year & 40\% Poverty rate & 50\% Poverty rate \\
Sweden & & & \\
Norway & 1995 & 0.8 & 2.7 \\
Luxembourg & 1995 & 0.9 & 14.0 \\
Finland & 1994 & 0.9 & 6.7 \\
Canada & 1995 & 1.2 & 5.4 \\
Netherlands & 1997 & 1.4 & 5.3 \\
France & 1994 & 3.3 & 6.4 \\
Denmark & 1994 & 3.4 & 9.8 \\
Spain & 1992 & 3.7 & 11.1 \\
Germany & 1990 & 3.9 & 11.3 \\
United Kingdom & 1994 & 4.0 & 7.0 \\
\hline
\end{tabular}

Source: Smeeding and Williamson, 2001.

Table 2. Pension Assets as Percent of GDP

\begin{tabular}{lrr} 
& 1987 & 1996 \\
Sweden & 33.4 & 32.6 \\
Denmark & 10.9 & 23.9 \\
Netherlands & 45.5 & 87.3 \\
Germany & 3.4 & 5.8 \\
France & - & 5.6 \\
Switzerland & 74.7 & 117.1 \\
United States & 35.7 & 58.2 \\
United Kingdom & 62.3 & 74.7 \\
\hline
\end{tabular}

Source: OECD (1998).

Note: The number for Sweden includes the assets in the publicly managed AP Funds. Bonoli (2003) reports a lower level of assets for Sweden, probably because the AP Funds are not included.

how public regulation affects the outcomes described above. The Danish and Dutch modes of public regulation of private supplementary pensions have resulted in near-universal coverage for wage earners.

How did our three pensions reach these destinations? The next section traces the historical development of pension arrangements, both public and private, in Sweden, the Netherlands and Denmark.

\section{Sweden}

The public pension system currently consists of three parts: the "guarantee pension," the "income pension," and the "premium pension." The guarantee pension, introduced as part of the 1994/98 reform, replaced the old basic pen- 
sion, and it is a "pension-tested" benefit that provides a basic benefit roughly equal to the combined value of the old basic pension and pension supplement. The "income pension" replaces the old ATP system and provides earningsrelated benefits based on lifetime earnings. Pension-qualifying income as well as benefits are indexed using a modified wage index. The 1994/98 reform also introduced the "premium pension:" $2.5 \%$ of pension-carrying income is placed in an individual investment account that pays retirement benefits based on investment returns. Guarantee pensions are financed by general revenues, while wage earners and employers finance the income and premium pensions. ${ }^{3}$

This set of pension arrangements replaced a similar, two part system: the basic pension provided a flat-rate benefit while the ATP system paid incomerelated pensions according to "defined benefit" principles. A full ATP plus basic pension paid $65 \%$ of average income based on the best 15 years of at least 30 years of employment, up to the benefit ceiling. Both tiers were PAYG and financed by employer contributions. In 1990, the basic pension contribution ( $7.45 \%$ of payroll) financed $85 \%$ of benefits (the state paid the rest), while the ATP contribution (13.5\% of payroll) financed both current benefits and the accumulation of savings in the AP funds. Both the basic pension and the ATP pensions were indexed to inflation.

This set of pension arrangements evolved over a comparatively long period. In 1914, the Liberal government introduced universal old age and invalidity pension insurance that was replaced by the more generous flat rate basic pension in 1935. In 1948, the basic pension was raised significantly so that by the early 1950 s it equalled about $30 \%$ of average industrial wages (Ackerby, 1992).

During the 1950s, two groups enjoyed generous occupational pensions: state and white collar employees. Manual workers led by the Trade Union Federation (LO) and backed by the Social Democratic Party (SAP) were eager to reduce this disparity. After several years of contentious debate, the SAP-led government managed to adopted an earnings-related pension scheme (ATP) in 1959 , over the vehement opposition of the non-socialist parties. ${ }^{4}$ In 1969 , the basic pension was complemented with the pension supplement for those not covered by ATP or who had a low ATP pension. This supplement was small at first, but was successively raised so that it corresponded to about half the basic pension in the early 1990s.

2. The total pension contribution is $18.5 \%$ of qualifying wages.

3. The state pays pension contributions for wage earners who are unemployed, pursuing higher education and/or military service, on parental leave, or sick leave.

4. For discussions of the ATP reform, see Heclo (1974), chapter five. 


\section{The 1994/98 Reform}

Prior to the 1990s, pension reform never occupied a prominent place on the political agenda. However, as the ATP system approached maturity, the Social Democratic government appointed an Official Commission of Inquiry in 1984 to evaluate the system and pinpoint reform needs. The commission deliberated for six years, producing a vast amount of expert analysis, but there was no agreement on the direction of reform (SOU 1990: 76). The TCO (Confederation of White Collar Workers) was the main opponent to reform, refusing to accept any change in the best 15 of 30 years benefit formula.

Sweden's economic crisis in the early 1990s ended the pension stalemate. Weak economic growth, rising unemployment, and a growing number of retirees led to unanticipated financial pressure on the pension system. A sharp deterioration in government finances exacerbated the pension system's problems. Between 1990 and 1993, Sweden went from budget surplus to recording a deficit of $12.3 \%$ of GDP, and open unemployment increased from $1.7 \%$ to $8.2 \%$, prompting massive reductions in public spending (Pontusson, 1992; Huber \& Stephens, 1998).

Pension reform reached the top of the political agenda in the middle of this economic crisis. The economic crisis also contributed to a change in government; the Social Democrats were defeated at the polls in 1991 by a nonsocialist minority coalition led by the Conservative Party. ${ }^{5}$ The non-socialist coalition now possessed the legislative initiative even if the SAP was still the largest party in parliament. Pension reform gathered further momentum when a series of expert studies revealed fundamental weaknesses in the pension system: the ATP system's sensitivity to economic swings and low growth; projected decreases in the AP Funds; the weak link between contributions and benefits; and the rising cost of basic pensions (Olsson \& Schubert, 1991; Bröms, 1990; Söderström, 1991; Lindbeck, 1992). The Swedish Employers Federation (SAF) also called for radical reform (Svenska Arbetsgivareföreningen, 1990).

Although the ATP system as a whole was in surplus because of reserves that accumulated in the 1960s and 1970s, the long term financial trend was cause for concern. Since the early 1980s, ATP payroll contributions no longer covered pension costs, so AP fund reserves were tapped to finance the shortfall. In 1982, the AP Funds had enough capital to finance benefits for 7.4 years without additional contributions. This measure of fund strength had declined to 5.1 years in 1992, fuelling fears of AP fund depletion (Riksförsäkringsverket, 1994). In addition, the growing cost of basic pensions contributed to the already dismal state of government finances.

5. The SAP served as a minority government from 1982-1991. 
With the major political parties backing some sort of reform, the only question was which party would control the reform negotiations. The maturity of the system precluded radical privatization, but reform offered the nonsocialist government the opportunity to introduce changes once considered nearly impossible, such as individual pension accounts. Because of its minority status, the coalition government was forced to seek outside support. Instead of turning to the volatile New Democracy Party, ${ }^{6}$ the government tried to assemble a broader reform coalition including the SAP. The SAP leadership had already come out in favour of reform, so cooperation with the non-socialist parties was seen as a painful necessity caused by the economic crisis as well as an opportunity to block any radical reform proposals. More important, a broad reform coalition would allow the SAP to work toward preserving the basic structure of the pension system and correct its perceived weaknesses.

Cooperation between the SAP and the four main non-socialist parties resulted in the passage of framework legislation in the Spring of 1994, followed by detailed legislation in 1998. The parties backing the reform negotiated in a small, closed working group rather than within the more open structure of an official commission. The working group structure was used for the duration of the reform process, from 1991 to 1998.

The reformed system differs from the existing system in several important ways. First, a notional defined contribution (NDC) system based on lifetime earnings replaces the best 15 of 30 years benefit formula in the ATP system. This tightens the link between contributions and benefits, and reduces some of the pension system's redistributive elements. Second, both employers and employees pay pension contributions, a change designed to increase public awareness of retirement costs. Third, a new index links benefits to wage developments and real economic growth and changes in average life expectancy. These changes mean that the pension system will be more resistant to economic swings and it will be self-financing regardless of the state of the economy. There is no formal retirement age. Fourth, spouses may share pension rights and military service, child rearing, and education will earn pension rights. Finally, $2.5 \%$ of the total $18.5 \%$ in pension contributions will be placed in an individual investment fund, the "premium reserve." In addition, the "guarantee pension" replaces the old basic pension and pension supplement. The transition to the new system will take 20 years (Proposition 1993/94: 250).

Five parties backed the pension reform, and the reform package reflects this inter-party bargaining. The Christian Democrats and Centre Party advocated shared pension rights for spouses, the SAP wanted to retain the obligatory system with high replacement rates, while the Liberals and Conservatives wanted a more explicit link between contributions and benefits, as well as the

6. The populist New Democracy party was voted into the Riksdag in 1991 . 
premium reserve. All of the political parties advocated the introduction of the notional defined contribution benefit structure, real wage indexing, and measures to promote financial sustainability. Although the influence of the SAP in the reform process has been substantial, they have acquiesced in three main areas: the structure of financing, shared pension rights, and the premium reserve system.

The new pension system provides lower benefits for some groups than the old ATP system, particularly those with less than 30 years of employment. However, these benefit losses should be considered in the context of the "improvements" introduced by the reform. The new pension system is resistant to economic and demographic shocks, and the new indexing rules will stop the erosion in the real value of ATP pensions. In the old system, accrued rights and benefit pay-outs were indexed to inflation. Since wages grow more quickly than inflation, a growing share of workers earned incomes above the pensionqualification ceiling, for which they accumulated no pension rights. This trend threatened to transform the ATP system into a generous basic pension and was a serious threat to the earnings-replacement function of the system. The new system also corrects the unintended redistribution from lower income groups to higher income groups because of the best 15 years of 30 benefit rule. Finally, the state remains responsible for providing a minimum level of provision for all citizens.

Why did the SAP cooperate in such a radical reform of the public pension system? Why did organized labour tacitly support the SAP's reform efforts? A non-socialist government passed the first stage of the reform (1994), but the SAP played a key role in the reform negotiations, and an SAP minority government adopted the subsequent provisions. The close ties between the SAP and the LO meant that union interests played an important role in the SAP's negotiating position, but this influence had its limits. Unions and other organized interests were deliberately excluded from the reform negotiations, and the political parties gave their negotiators an unusual degree of independence to work out a compromise. This strategy resulted in the minimization of veto points and the depoliticisation of the pension issue (cf. Immergut, 1992; Bonoli, 2000). All parties agreed to compromise at an early stage, and they used the structure of the working group to strengthen their bargaining power versus the unions and other organized interests (cf. Anderson, 2001; Anderson and Meyer, 2003).

The Social Democratic Party and organized labour emerge as central actors in this brief account of the development of Swedish pensions. The ATP struggle was one of the great political victories of the SAP in the postwar period and ushered in a long period of Social Democratic dominance. The nonsocialist parties reluctantly accepted the basic features of the pension system, but the 1990s brought an opportunity for reform. The pension system remained 
popular with voters, but economic and demographic trends threatened the future sustainability of the pension system. As their electoral dominance waned, the SAP leadership opted for compromise with the non-socialist parties, and in contrast to the heated conflict that led to the 1959 ATP reform, a five party coalition negotiated the1994/98 reform.

\section{The Netherlands}

The development of the Dutch pension system is marked by a comparatively late start followed by the swift expansion of benefits. Confessional political parties and interest organizations have heavily influenced Dutch politics (see Cox, 1985; van Kersbergen, 1995) and these cleavages have left their mark on both public and private occupational pensions. ${ }^{7}$

The pillarisation of Dutch society into four main groups (socialists, liberals, Catholics, and Protestants) significantly shaped early pension policy. The first pension law was adopted in 1913, but it covered only workers. Although the Labour Party (PvdA) and Liberals (VVD) advocated universal coverage, the confessional parties prevailed in their preference for employment-based pensions with corporatist administration. Confessional groups wanted to limit the role of the state so they pushed for pensions to be administered by corporatist bodies with representatives of employers and unions and the National Insurance Bank (NIB). This type of administrative arrangement would set a strong precedent for all subsequent social welfare legislation.

WWII marked a turning point in Dutch welfare state development. The government in exile in London appointed a commission to plan for future social reforms, headed by a leading Labour Party member (van Rijn). Mindful of the earlier rejection of universal pensions, the commission recommended universal pension insurance. Reformers wanted universal, equal benefits for all, but these would be "earned" by residence and financed by wage earner contributions, thereby creating solidarity between wage earners and non-wage earners. The contribution ceiling was set fairly low, about equal to average earnings, so as not to discourage the development of occupational pensions.

The immediate postwar period saw a succession of "Red-Roman" governments in which the Labour Party governed with the confessional parties. After the 1946 election, the Labour Party leader DeVrees served as Minister of Social Affairs. Conditions seemed favourable for a pension reform of Labour's making, but pillarisation had survived the war, and conservative confessional groups opposed Labour's pension reform plans. Minister DeVrees secured adoption of an Emergency Pensions Act in 1946 to serve as an interim

7. This section is based on Cox (1985); Jaspers et al. (2001); and Rigter et al. (1995). 
measure until a permanent system could be negotiated. The measure passed with the votes of the Catholic Party after the Labour Party agreed to base the scheme on the insurance principle (see above). The Emergency Act provided benefits to all persons over 65 , including those with occupational pensions. Despite cooperation of the Catholic Party, corporatist interests were divided, especially concerning administration. However, the Emergency Act set in motion a process in which all citizens were entitled to a public pension. Negotiations on permanent legislation dragged on for ten years, but the Labour-controlled Ministry of Social Affairs finally prevailed, negotiating the provisions of the permanent legislation with the newly created Social Economic Council (SER), a tripartite corporatist advisory body. The Emergency pensions had been in effect for nearly ten years and were very popular, prompting the Liberals and more moderate Catholics to side with Labour. The reform was adopted by Parliament in 1956, and the new law, the AOW went into effect on January 1, 1957.

Labour's ability to secure Catholic Party support for a temporary pension arrangement in 1946 had a decisive impact on the fate of the basic pension. The emergency legislation was intended to be temporary but as the parliamentary stalemate over permanent legislation continued, citizens started to get used to the new pensions and they liked the new arrangement. To use the language of path dependence, the emergency legislation set the Netherlands on the path of a universal, public, basic pension, and ten years of legislative stalemate greatly increased the costs of departing from this path (Thelen, 1999; Pierson, 2000). The new pensions were popular enough to convince moderate Catholics to embrace the reform and embolden the SER to ignore the opposition of conservative Catholics. In sum, a relatively weak left was forced to compromise with powerful confessional parties, but the left was able to overcome this opposition with clever bargaining and luck. Clever bargaining led to LabourCatholic Party agreement over emergency pension legislation, while the ten year policy stalemate turned out to be a crucial advantage for Labour. Every year the parliamentary deadlock continued was a year in which more and more citizens began to draw pension benefits, thereby contributing to their popularity and emerging status as a social right.

Today, the AOW is financed by wage-earner contributions (17.9\% of income), and 50 years of residence are required for a full pension. In 2003, the full net pension benefit for a single person was $70 \%$ of the net minimum wage, or about EUR 840 net per month for a single pensioner. For married pensioners the net pension is $50 \%$ of the net minimum wage, or about EUR 600 for each spouse. In 1998, AOW spending equalled $4.8 \%$ of GDP and provided benefits to 2.2 million pensioners (Ministry of Social Affairs and Employment, 2001: $6)$. 
Growing pension commitments have necessitated significant increases in contribution rates. Since 1957, the contribution rate has increased steadily from $6.75 \%$ of income to $17.9 \%$ in 2001 , and expert analyses frequently warn of even higher contributions. ${ }^{8}$ Policymakers have responded in two main ways. First, there is political agreement on the need to increase labour force participation and broaden the tax base without increasing non-wage labour costs or income taxes. Second, a 1998 law introduces partial funding into the AOW system by requiring the government to contribute EURO 115 million per year to the AOW Savings Fund. Reserves and interest earned by the fund are intended to help finance future AOW costs.

In addition to these explicit strategies, governments have followed an implicit strategy of shifting the costs of retirement to occupational pensions. The overwhelming majority of occupational pension schemes provide a defined benefit that includes the AOW. If governments limit the growth of AOW benefits (by suspending indexing, for example), this creates pressure on occupational pensions to make up the difference. This is exactly what has happened during the past 20 years (Clark, 2003).

\section{Occupational Pensions}

Occupational pensions are regulated by the state but the social partners negotiate pension arrangements as part of collective labour agreements. In 1999 , there were 947 different pension funds, including industry-wide pension schemes, company pension schemes, pension funds for the self-employed and other schemes, such as the ABP system covering civil servants (SER, 2000: 27). In 1998, employers paid $6.7 \%$ of their wage bill into second pillar schemes, while employees paid 2.3\% of their wages (Ministry of Social Affairs and Employment, 2000: 6). Until recently, the typical benefit formula was 70\% of the final salary, including the AOW, after 35 to 40 years of employment. Although occupational pensions are organized within the market, social solidarity is promoted by several features. Coverage is nearly universal; unions and employers are equally represented on pension fund governing boards; and risks are pooled within entire sectors (Clark, 2003).

By the 1990s, occupational pension growth prompted calls for cost containment. Like the AOW, the occupational pension system faces substantial demographic pressure, so reform efforts emphasize reducing costs, especially for future retirees. Since most occupational pensions are defined benefit, final salary schemes, costs will increase substantially as individual pension schemes

8. See for example, Nelissen (1994). 
mature. In response, many pension schemes have switched to average earnings formulas (SER, 2000). In 1987, about 77 percent of wage-earners participated in final pay schemes, about 14 percent participated in average earnings systems, with the rest covered by other benefit formulas. In 1999, the number of participants in final pay schemes had decreased to about $62 \%$ and the number in average career earnings schemes had increased to 25\% (SER, 2000: 161).

Recent policy changes also emphasize reducing the male breadwinner bias in supplementary pensions and increasing coverage to new groups, especially part time workers and workers with fixed contracts. In 1997 the Social and Economic Council (SER) facilitated the negotiation of a "Pension Covenant" between the social partners and the government. The government and social partners were particularly concerned about controlling pension costs because of their share in total labour costs; increasing the coverage of supplementary pensions; and modernizing benefit rules in order to increase flexibility and individual choice (Stichting van de Arbeid, 1997). In particular, the social partners agreed to reduce reliance on final pay benefit schemes and to expand coverage of part time and flexible workers. The results of the covenant have been evaluated positively (SER, 2001) but the recent stock market downturn has led to tense discussions about the regulations governing the coverage rate of supplementary pensions. Most pension tunds have significant investments in stocks (30-40\% of assets), and the bear market has led to heavy losses. The reserves of many pension funds fell below the $100 \%$ coverage rate for the first time in 2002. The drastic deterioration of the financial position of many funds prompted the pensions regulator, PVK, to demand tougher rules governing pension fund solvency. For most funds, restoring solvency means increasing premiums, suspending the indexation of pensions, or both. For example, the Netherlands' largest pension fund, ABP (for civil servants) raised premiums from $13 \%$ to $15 \%$ of qualifying income, and announced a switch from final salary benefit formula to average career earnings formula starting in 2004.

The pillarisation of Dutch society has significantly influenced the shape and development of occupational pensions. Confessional groups opposed statist arrangements because they wanted to retain confessional influence on the scope and administration of social policies. In contrast to Sweden and Denmark, the introduction of a public occupational pension system has never been seriously considered in the Netherlands. First, funded occupational pensions have a long history in the Netherlands, and occupational pensions are explicitly seen as an instrument of wage policy. Occupational pensions are negotiated as part of wage contracts so transferring them to the public sector would deprive unions and employers of important bargaining tools. The state provides a regulatory framework for occupational pensions, but the social partners have considerable freedom to negotiate the details of occupational pensions, and they jealously guard this prerogative. Second, the initially 
uneven coverage of occupational pensions meant that "lock-in" effects generated a powerful coalition in favour of extending the existing system to new groups rather than transforming it into one public scheme. Unions and employers that negotiated the first occupational schemes did not want to relinquish this tool of wage bargaining, so workers without occupational pension coverage had every incentive to try to achieve coverage through collective bargaining. As the popularity of occupational pensions increased, the state stepped in to provide incentives for extending coverage to new groups (see below).

\section{Denmark $^{9}$}

The current pension regime in Denmark includes four parts: the income-tested basic pension; the modest ATP scheme; funded labour market pensions providing earnings-related pensions for nearly all employees; and voluntary private pension savings accounts. Assets in the latter three schemes are considerable: ATP assets equal 19\% of GDP, capital in labour market pension funds totals $29 \%$ of GDP, and assets in private individual insurance accounts amount to $29 \%$ of GDP.

The Danish public pension resembles the Swedish except for the small size of the ATP and the larger size of collectively bargained occupational pensions. Denmark introduced public old-age pensions very early, in 1891. 1922 legislation expanded pension coverage, but it was not until 1956 that benefits became universal. In 1964 benefits were improved and an income-tested supplement was introduced. Today, the basic pension is income-tested, but few pensioners fail this test and lose their public benefits.

As Esping-Andersen (1985) notes, Danish social democrats had the misfortune of facing strong liberal competition in social welfare policy, so Danish social policies are a curious blend of social democratic and liberal values. When the social democrats joined with liberals to improve the basic pension scheme, they had to accept generous tax incentives for private pensions.

The inability of the Social Democrats and trade unions to dominate postwar pension politics meant that developments proceeded along two tracks. First, liberals and social democrats supported the expansion of the basic pension. Second, development toward a Swedish-style ATP stalled. The liberals and conservatives feared that a public supplementary pension scheme would lead to politically controlled investment funds. The Social Democrats themselves were divided on the issue. Many Social Democrats opposed a public pension

9. Unless otherwise noted, this section is based on Green-Pedersen (2003); Ploug (2001); EspingAndersen (1985); Plovsing (1997); and Ministry of Social Affairs (2001). 
system that would reinforce income differentials among wage earners and preferred instead to address benefit inadequacies within the structure of the existing pension system. The deadlock resulted in the expansion of the basic pension, the introduction of the ATP, and increased take-up rates for individual private pensions.

Danish social democratic attempts to introduce public supplementary pensions were a notable failure. The LO campaigned to introduce a Swedishstyle ATP in the early 1960 s, but this resulted only in watered down legislation passed by the Social Democratic coalition in 1964. Unable to legislate substantial public supplementary pensions, the government opted for the small ATP and improvements in the basic pension in 1964 (see above). The Social Democrats' task was surely made more difficult by the cumulative impact of tax incentives for private pensions passed earlier. Unlike Swedish social democrats, the Danes had no formula for attracting the middle classes to their political project via public, supplementary pensions. The ATP provides a flat rate benefit based on previous hours worked rather than income. Only wage earners pay contributions, and despite the small size of this program, accumulated assets equal more than $19 \%$ of GDP.

For many low wage earners, the basic pension and the modest ATP benefits provided adequate pension coverage. In contrast, higher income earners, like the metalworkers, experienced a significant drop in income after retirement because of the inadequacy of the basic pension and ATP in relation to previous wages. It was precisely this group that led the effort to improve earnings related pension coverage among private sector workers. However, the metalworkers would have to wait much longer than their counterparts in the public sector.

The vacuum left by the failure of ATP has been filled with a variety of labour market related pensions. In the early 1960s, when the political establishment could not agree on the introduction of supplementary pensions, such a scheme was introduced for wage earners in the public sector. As the welfare state expanded, supplementary pensions for teachers, nurses, and other professionals were a way to enhance the attractiveness of public sector employment. According to Ploug (2001), this move set a decisive precedent for the rest of the labour market twenty years later.

By the 1980s, the Social Democrats and liberals had changed their positions regarding occupational pensions. One important economic factor was persistent deficits on the current account, caused by Denmark's low savings rate (among other things). The accumulation of pension savings was one way to address this. Another contributing factor was the demands of some LO unions for improved supplementary pension coverage, particularly the Metalworkers Union. At the time, however, wage bargaining negotiations were centralized, and this precluded the Metalworkers and other unions from negotiating supplementary 
pensions as part of wage contracts. Separate pension agreements could only be negotiated on a lower level and existing institutions ruled this out.

By the mid 1980s, the Metalworkers advocated a centralized solution to their pension concerns and demanded that LO work towards a legislated, centralized system. Other unions opposed the Metalworkers demands, however. The low wage unions in the LO, who were basically satisfied with the coverage of existing arrangements, feared that making occupational pensions the centrepiece of their bargaining with the non-socialist government would distract attention from other bargaining issues. In addition, the lower wage unions argued that occupational pensions would reinforce income inequality in retirement.

These divisions among the LO unions were mirrored in the Social Democratic Party. The party was already divided on the issue of occupational pensions because of fears similar to those of low wage LO unions: occupational pensions would reinforce income inequality in retirement. Despite these divisions, in 1985 the LO and Social Democratic Party agreed on a proposal for economy-wide, funded, supplementary pensions. Wage earner representatives would manage the fund capital.

The non-socialist government headed by Poul Schlüter supported the expansion of occupational pensions, but the coalition opposed the LO-Social Democratic Plan as did the employers. Despite what appeared to be a united LO-Social Democratic front, both the unions and the Social Democrats continued to be internally divided on the issue, and the proposal ultimately failed. Social Democratic opponents advocated further expansion of the basic pension instead. The non-socialist government, employers and unions finally agreed on the outlines of a decentralized system of occupational pensions in 1989. By now, Denmark's competitiveness position had deteriorated significantly and there was widespread support for wage moderation and higher savings to offset the current account deficit. The LO was now prepared to accept collectively bargained occupational pensions to improve coverage for its middle and higher income members. The Social Democrats remained opposed to the non-socialist government's plans for expanding labour market pensions, preferring a legislative solution. In order to increase the pressure on the Social Democrats to cooperate with the minority coalition to adopt occupational pension framework legislation, the LO began negotiations with the employers and the government. At first the strategy worked, and the government initiated negotiations with the Social Democrats, but the talks soon broke down. By now, the LO considered its alternatives to be exhausted and viewed decentralized labour marked pensions as the only remaining solution to its occupational pension problem (Green-Pedersen, in press).

The first steps toward this new model were taken in 1989 when unions for unskilled public sector workers negotiated a separate pension deal. Metalwork- 
ers took similar steps in 1991, setting a precedent for the rest of the private sector. Most occupational schemes are defined contribution. The coverage rate of occupational pensions was $84 \%$ in 1997 , up from about one third in the late 1970s.

Why did unions finally accept the expansion of funded, decentralized labour market pensions as the solution to their pension dilemma? First, the unions wanted some control over pension fund governance, but this was precisely the issue on which the non-socialist government would not budge. Particularly the Liberal Party was immovable on this issue. Similarly, the Social Democratic opposition was resolute in its resistance to decentralized pension funds. The distance between the government coalition and the Social Democratic opposition was too great to permit any sort of compromise on this issue. For the LO, participation in pension fund governance (with employers) was a second best option that it accepted in order to finally improve pension coverage for its middle and higher income members. Moreover, union participation in pension fund administration had advantages: influence over investment decisions and selective incentives for workers to join unions participating in pension plans (Green-Pedersen, in press).

\section{The Three Pension Systems Compared}

Bonoli (2003) argues that European pension systems cluster into two groups, "social insurance countries" and "multipillar" countries. In social insurance countries, public arrangements dominate retirement income provision, and the private and occupational pension sectors are relatively small. In multipillar countries, the state provides only a minimum pension while occupational and private arrangements provide additional benefits. In Bonoli's scheme, Sweden (along with Germany and France) is a social insurance country while the Netherlands and Denmark are multipillar countries (along with the United Kingdom and Switzerland). The institutional structure of pension provision heavily influences the logic of change in each cluster. In social insurance countries, politicians legislate changes in benefit levels and contribution rates. In multipillar countries, the public pension sector is small, so politicians' responsibility for making potentially difficult decisions is more limited than in social insurance systems. Instead, private actors (firms, unions, pension funds) are responsible for adjusting pension levels and contribution rates to changing economic and demographic conditions. This implies that change should be easier in multipillar countries than in social insurance countries because electoral risks are low.

This article takes issue with Bonoli's arguments in two ways. First, the article demonstrates that despite differences in institutional structures, the Swedish, Danish and Dutch pension systems produce broadly similar social 
outcomes. Even though Denmark and the Netherlands have large private occupational pension sectors, Dutch and Danish old age poverty rates and income equality are similar to Sweden's. Moreover, Dutch and Danish private occupational pensions display important elements of solidarity: coverage is nearly universal, unions and employers administer pension funds, and risks are pooled within entire sectors (Clark, 2003). Bonoli's classification does not capture these similarities.

Second, the distinction between multipillar and social insurance countries probably overestimates differences in the logic of change typical of each cluster. Denmark and the Netherlands are multipillar countries with relatively large public pension sectors. Current public pension spending in both countries is roughly equal to private occupational pension expenditures. Similarly, about half of Dutch pensioners currently receive an occupational pension, and the proportion is similar in Denmark. Thus it may be possible that multipillar countries will exhibit two logics of change, the electoral logic associated with the public basic pension and the market logic associated with private occupational pensions. However, it is also plausible that the logic of change depends on institutional features of pension schemes common to both public and private pensions. Features of the reformed Swedish system (NDC, automatic stabilizers) vastly decrease the need for political intervention to adjust contribution rates and benefits and make it arguably more stable than a multipillar system like the Dutch. Dutch private actors (pension fund boards) have recently cut indexing and raised contributions but the context is highly politicized as private actors call for improved pension fund regulation and supervision.

Despite recent stock market losses, occupational pensions in the Netherlands and Denmark will continue to grow in importance, and as they grow, the three pension systems will increasingly diverge in terms of social outcomes. Dutch spending on supplementary pension benefits (about 4\% of GDP) is nearly equal to AOW spending ( $4.3 \%$ of GDP). Today, more than $90 \%$ of wage earners participate in a supplementary pension plan, but only $50 \%$ of current pensioners receive supplementary pension income (Carey, 2002). As the number of retirees with supplementary pension income increases, income distribution among retirees is likely to more closely resemble the income distribution among wage earners than is currently the case. Moreover, if the trend away from final pay to average earnings benefit formulas continues, as is likely, this will result in growing differences in supplementary pension income among retirees. Both of these long term trends will lead to greater inequality among pensioners.

The Danish occupational pension sector is likely to exhibit similar effects, with a somewhat different dynamic. Unlike the Netherlands where nearly all supplementary pensions are defined benefit, most Danish occupational pen- 


\section{Canadian Journal of Sociology}

sions are defined contribution. Like the Netherlands, the growing maturity of occupational pension plans will almost certainly lead to increased inequality among pensioners as those with higher incomes during employment receive higher retirement incomes. However, the defined contribution structure of Danish occupational pensions will mean that wage earners bear the investment risks associated with pension savings. Thus pension benefits will reflect not only differences in previous income but also differences in investment performance. All of this is likely to add up to increased inequality unless offset by income tax measures.

The Swedish pension system is also likely to experience increased inequality among retirees as the reformed pension system matures. The lifetime earnings benefit formula will result in greater income differences among retirees, as will the income from the new premium pension. However, given that a smaller share of pension income is managed privately, the trend towards increased inequality is likely to be weaker in Sweden than in Denmark and the Netherlands.

The impact of pension system maturity on the organization of pension savings also deserves comment. The Swedish, Danish, and Dutch pension systems all have comparatively high levels of pre-funding, but the structure of pension assets differs substantially. Sweden stands out for the large public pension funds built up in the decades after the introduction of the ATP system. These funds were primarily used to finance affordable housing (among other things) and only later were relatively small amounts invested in equities. One of the most significant effects of the 1994/98 pension reform will be the gradual reduction of the AP Funds. In 1992, the AP Funds amounted to more than $30 \%$ of GDP, but by 2001 their level had fallen to $22.4 \%$ of GDP. ${ }^{10}$ Part of this decline is due to stock market losses in 2000 and 2001, but the reform implies that the downward trend will continue for two reasons. First, the AP Funds financed some of the costs of switching to the new system ${ }^{11}$ and second, the AP Funds will continue to pay some of the costs of the new income pension. Moreover, as the AP Funds decrease, the assets in the new premium reserve will increase, and in two to three decades will exceed those of the AP Funds. This long term trend amounts to a gradual privatization of pension savings in Sweden, and a major victory for the non-socialist parties.

Finally, the impact of the benefit formula on financial sustainability merits discussion. The Dutch case demonstrates that $100 \%$ funding requirements are not necessarily the best route to financial stability, at least when combined

10. Own calculation, from Regeringens skrivelse 2002/03: 130, Redovisning av AP-fondernas verksamhet 2002.

11. See Anderson and Weaver (2003) for details. 
with defined benefit pensions. The recent bear market has resulted in significant losses for most Dutch pension funds and prompted drastic premium increases and/or benefit cuts. The effects of supplementary pension policy are thus pro-cyclical. In the current downturn, premium increases and reduced pensions lead to a reduction of already-shrinking purchasing power. The same is true during an economic expansion; as pension fund returns increase, premiums can be reduced and pensions increased, resulting in increased purchasing power for firms and consumers. These developments can fuel inflation and lead to an overheated economy. In other words, the functioning of the supplementary pension system contributed to an overheated economy in the late 1990s and is exacerbating the current recession. Economic developments during the past decade demonstrate the weaknesses of the Dutch supplementary pension system, and policymakers have only begun to grapple with these problems.

In contrast to the Netherlands, the Danish and Swedish pension systems are more financially stable. The recent Swedish reform includes automatic stabilizers, including the switch to the notional defined contribution structure, the introduction of a life expectancy index, and other balancing mechanisms. ${ }^{12}$ Danish occupational pensions are similarly less vulnerable to short term economic swings, but this is largely because pensions are defined contribution. Individuals bear the risks associated with fund performance, but they do so over a long period of time as they accumulate pension savings, so the effects of short term economic swings are not felt as immediately and as strongly as they are in the Netherlands.

\section{Conclusion}

This article emphasizes the political mobilization of the left and its coalitions with other societal groups in accounting for the development of pension regimes in Sweden, Denmark and the Netherlands. The political strength of the Swedish SAP in alliance with the trade unions contributed to the emergence of a statist pension system. In the Netherlands and Denmark, divisions within the trade unions and within the Danish Social Democratic Party had important effects on the organization of supplementary pensions. In both countries, a politically weak and divided left settled for collectively regulated but privately organized supplementary pensions.

Given their political weakness, how did the Left in Denmark and the Netherlands achieve pension policy outcomes similar to those achieved by a strong Left in Sweden? First, the Left in Denmark and the Netherlands were 
important players in the introduction of the universal basic pension, which is crucial for explaining low poverty rates in Denmark and the Netherlands (and Sweden). The Dutch Labour Party joined with the Catholic Party to introduce emergency pension legislation immediately after World War II, and the subsequent pension deadlock led to the entrenchment of emergency pensions. The Danish Liberal Party joined with the Social Democrats in the establishment and expansion of the basic pension.

Second, divisions internal to Danish unions and the Social Democratic Party hampered efforts to legislate occupational pensions, but union strength ensured that occupational pensions were part of wage contracts at the sectoral and not the firm level. To the extent that unions pursue the goals of solidarity and equality in their wage (and pension) negotiations with employers, these values will be reflected in the design of occupational pension schemes. And as noted, lower income wage earners already received adequate coverage via the basic pension and the ATP, so the structure of the growing labour market pension sector mainly applies to middle and higher income groups.

The Dutch Labour Party and unions never seriously campaigned for public supplementary pensions. Labour defined the pension issue as expanding basic coverage, rather than legislating occupational pensions. Like Danish unions, unions in the Netherlands possess enough bargaining strength to pursue strategies based on solidarity and equality (cf. Myles and Pierson, 2001). In other words, collective bargaining provides an opportunity for union influence even when the legislative route to occupational pension coverage has been closed off.

The experiences of Denmark and the Netherlands suggest that different pension regimes are capable of producing "social democratic" outcomes such as poverty alleviation, reducing income inequality, and covering various risk profiles. While mandated private supplementary pensions may produce social democratic social outcomes, the dominance of state provision does seem crucial for producing social democratic political outcomes. Labour's political weakness in the Netherlands and Denmark contributed to its inability to achieve more than the basic pension in the public pension sphere. Moreover, union fragmentation along religious lines in the Netherlands and along craft lines in Denmark made it difficult for labour to pursue a unified strategy concerning supplementary pensions. Over time, the development of supplementary private pensions in both countries reinforced labour's weakness. Whereas the Swedish Social Democrats used the supplementary pension issue to mobilize middle class support, this strategy failed in Denmark and was never really attempted in the Netherlands.

Myles and Pierson (2001) argue that pensions are a classic case of path dependent change, and this article confirms this claim. Given that governments and pension funds make pension promises decades in advance, the notion of 
a "path" is inherent in pension development, and actors adapt their behaviour to the prevailing structure of pension provision. In all three countries, initial choices concerning the structure of basic and occupational pensions significantly shaped subsequent pension development. One of the reasons the conflict over Swedish ATP pensions was so bitter is that the non-socialist parties understood the long-term implications of the SAP plan: citizens would adapt to the public system, private savings would decrease, and as each year passed it would be more difficult to switch to a privately organized system. In the 1990s, however, the ATP system was not irrevocably "locked in," and the nonsocialist parties exploited the political opening created by their 1991 election victory to negotiate substantial changes to the ATP system. Ironically, the existence of large buffer funds in the ATP system assisted the non-socialists in their efforts because the capital in the funds could be used to finance the transition to the new system. Without this financial cushion, elements such as the premium reserve would have been financially impossible.

Past choices also decisively shaped Danish and Dutch pension development. Social Democratic attempts to introduce a Swedish-style ATP in the 1960s were hampered by the earlier growth of private and occupational pensions that continued to expand as the Left tried to legislate comprehensive occupational pensions. A similar dynamic characterized Dutch basic pensions: during ten years of deadlocked pension negotiations, the 1946 emergency pensions became very popular and citizens adapted their retirement savings strategies to this scheme. By 1956, the entrenchment of the emergency pensions gave the Labor Party sufficient resources to secure adoption of the AOW law.

\section{References}

Anderson, Karen M. and R. Kent Weaver

2003 "Pension Politics in Sweden: Fundamental Reforms in a Policy Cartel." Unpublished Manuscript.

$\rightarrow$ Anderson, Karen M. and Traute Meyer

2003 "Social Democracy, Unions, and Pension Politics in Germany and Sweden" Journal of Public Policy, 23 ( 1): 23-54.

Anderson, Karen M.

2001 "The politics of retrenchment in a Social Democratic welfare state. Reform of Swedish pensions and unemployment insurance." Comparative Political Studies 34 (9): 1063-1091.

Bonoli, Giuliano

2000 The Politics of Pension Reform. Cambridge: Cambridge University Press.

$\rightarrow 2003$ "Two Worlds of Pension Reform in Western Europe." Comparative Politics 35 (4): $399-415$.

Carey, David

2002 "Coping with Population Ageing in the Netherlands." Economics Department Working Papers no. 325. OECD: Paris. 
Clark, Gordon L.

2003 European Pensions and Global Finance. Oxford: Oxford University Press.

Cox, Robert

1993 The Development of the Dutch Welfare State. Pittsburgh: University of Pittsburgh Press.

Disney, Richard and Edward Whitehouse

2001 "The economic well being of older people in international perspective: a critical review." Unpublished Manuscript.

Esping-Andersen, Gøsta

1985 Politics Against Markets. Princeton: Princeton University Press.

1990 The Three Worlds of Welfare Capitalism. Princeton: Princeton University Press.

Green-Pedersen, Christoffer

In press "Det danske pensionssystems endelige udformning. Kampen om pensionssystemet under Schlüter-regeringerne." Historisk Tidsskrift.

Heclo, Hugh

1974 Modern social politics in Britain and Sweden. From relief to income maintenance. New Haven: Yale University Press.

$\rightarrow$ Huber, Evelyne; Charles Ragin; John D. Stephens

1993 "Social Democracy, Christian Democracy, Constitutional Structure, and the Welfare State." American Journal of Sociology, 99 (3): 711-749.

Huber, Evelyne \& John D. Stephens

1998 "Internationalization and the Social Democratic model. Crisis and future prospects." Comparative Political Studies, 31 (3): 353-397.

Jaspers, A. et al.

2001 De gemeenschap is aansprakelijk...Honderd jaar sociale verzekering 1901-2001. Den Haag: Koninklijke vermande.

Immergut, Ellen

1992 Health Politics. Cambridge: Cambridge University Press.

Lindbeck, Assar

1992 Klarar vi pensionerna? Stockholm: SNS Förlag.

Ministry of Finance. Denmark

2001 A Sustainable Pension System. Copenhagen: Ministry of Finance.

Myles, John and Paul Pierson

2001 "The comparative political economy of pension reform." In Paul Pierson, ed., The New Politics of the Welfare State. Oxford: Oxford University Press.

Nelissen, Jan H.

1994 Towards a Payable Pension System. Tilburg: TISSER

OECD

1999 Maintaining Prosperity in an Aging Society. Paris: OECD.

2003 Sweden. Ageing and Employment Policies. Paris: OECD.

Olsson, Hans, \& Schubert, Göran

1991 Ds 1991: 27. Det framtida pensionssy'stemet: två alternativ. Stockholm: Allmänna förlaget.

Pierson, Paul

1994 Dismantling the Welfare State? Reagan, Thatcher, and the Politics of Retrenchment. Cambridge: Cambridge University Press.

1998 "Irresistible forces, immovable objects: post-industrial welfare states confront permanent austerity," Journal of European Public Policy 5 (4): 539-560. 
2000 "Increasing Returns, Path Dependence and the Study of Politics," American Political Science Review 94 (2): 251-67.

Ploug, Niels

2001 "Det danska ålderspensionssystemet - ful ankunge eller vacker svan?" in Joakim Palme, ed. Privata och offentligapensionsreformeriNorden. Stockholm: Pensionsforum

Plovsing, Jan

1997 Socialpolitik $i$ velfardsstaten. Copenhagen: Handelshöjskolens Forlag.

Pontusson, Jonas

1992 "At the end of the third road: Swedish social democracy in crisis." Politics and Society, $20,305-332$.

Proposition 1993/94: 250.

Regeringskansliet, Finansdepartementet

2002 Regeringens skrivelse 2002/03:130. Redovisning av AP-fondernas verksamhet 2002.

Regeringskansliet, Finansdepartement,

1998 AP-fonden och det reformerade ålderspensionssystemet, Ds 1998:7.

Rigter, D. et al

1995 Tussen sociale wil en werkelijkheid. Den Haag: VUGA.

Riksförsäkringsverket.

Various

years Social insurance statistics. Facts. Stockholm: Riksförsäkringsverket

Rothstein, Bo

1992 "Labor-market institutions and working-class strength." In Sven Steinmo, Kathleen Thelen, and Frank Longstreth, eds., Structuring Politics. Historical Institutionalism in Comparative Analysis. Cambridge: Cambridge University Press.

SER

2001 Rapport evaluatieonderzoek convenant arbeidspensioenen. Den Haag: SER.

Smeeding, Timothy M. and James Williamson

2001 "Income Maintenance in Old Age: What can be Learned from Cross-National Comparisons.” Luxembourg Income Study Working Paper No. 263.

Söderström, Hans. Tson. ed.

1991 Sverige vid vändpunkten. Konjunkturrådets rapport 1991. Stockholm: SNS Förlag.

Ståhlberg, Agneta

199.0 Våra pensionssystem. Stockholm: SNS Förlag.

Statens Offentliga Utredningar

1990 Allmän pension. Report no. 76.

1994 Reformerat pensionssystem. Report no. 20.

Stephens, John D., Huber, Evelyne, \& Ray L.

1999 "The welfare state in hard times." In Herbert Kitschelt, Peter Lange, Gary Marks, and John D. Stephens, eds. Cambridge: Cambridge University Press.

Thelen, Kathleen

1999 Historical Institutionalism in Comparative Politics. Annual Review of Political Science. 2: 369-404.

Trommel, Willem

1995 Korter arbeidsleven: De wording van een rationele mythe. Den Haag: Sdu Juridische and Fiscale Uitgeverij.

Van Kersbergen, Kees

1995 Social Capitalism. London: Routledge. 


\section{Canadian Journal of Sociology}

Visser, J., \& Hemerijck, A.

1997 A Dutch miracle. Job growth, welfare reform and Corporatism in the Netherlands. Amsterdam: Amsterdam University Press. 